\title{
Female Officers on Board: Prejudices, Stereotypes and the Leadership Role
}

\author{
Jose R Cordon ${ }^{1}$ (D), Nieves Endrina Sánchez ${ }^{2}$ (D) and Jose M Mestre Navas ${ }^{3}$ (D)

${ }^{1}$ INDESS-Universtity of Cadiz (Spain), Avda. de la Universidad, 4 (Campus de la Asunción), 11406, Jerez de la Frontera, Cádiz, Spain

${ }^{2}$ Deparment of Sciencies and Techniques of Navigation and Naval Construction, University of Cadiz, Spain

${ }^{3}$ Department of Psychology, Facultad de CC de la Educación, Universidad de Cádiz, Spain

\begin{abstract}
Seafaring is probably one of the most challenging working environments for a woman. For the last twenty years, women are increasing their presence in the fleet, particularly in western countries, but still the footprint in leadership roles aboard is minimal when compared to other jobs. This paper is based on a survey answered by 154 female officers from 18 countries. This survey comprises the following areas: Socio-Demographic, Labour, Work-Life Balance, Leadership Style, Harassment situations and an open section, all studied under the theory of Role Congruence. The main purpose is to determine the type of prejudice that can arise in this environment, as well as to clarify the role of women leadership. The secondary purpose is gathering data about the challenges that women face on board as Officers. We expect to find prejudice, cultural differences, harassment situations and different leadership style, but our hypotheses were not confirmed.
\end{abstract}

Keywords

Female officers, Seafaring, Mariners, Leadership, Prejudice

\section{Female Officers on Board: Prejudices, Stereo- types and the Leadership Role}

Nowadays, there is an increasing interest about the role of women in traditional male work positions. In particular, in the area of transportation, were women has been considered for years to play a secondary role, such as hostesses or flight attendants, cleaners or another kind of work that does not require special skills or academic preparation [1].

Meanwhile, particularly in Western Europe, many women entered in Seafaring Academies and started to sail as Officers for the last twenty years [2], but still the presence of women in leader roles aboard is minimal when compared to other jobs such as enterprise management, law and health-related disciplines. First, the state of the question and the current research panorama will be discussed.

\section{The International Maritime Organization (IMO) policy}

International Maritime Organization-IMO, is the United Nations specialized agency responsible for the safety and security of navigation and the prevention of marine pollution from ships.

In this particular the IMO [3], has promoted a policy of integration of women in managerial positions, both on board and ashore.

Although, in western countries it is common to see women as Officers, there is still a long way to go before reaching full equality. For this, IMO has launched a series of films focused on work on board women. The organization estates that more women are needed on board, especially in leadership roles.

Additionally, the IMO Program on the Integration of Women in the Maritime Sector [4] encourages maritime academies to promote the presence of women; in this way they can reach the highest levels of competence.

The Busan declaration [5], guides the IMO policy, therefore the organization is committed to fight for the effective

*Corresponding author: Jose R Cordon, Universidad de CádizEscuela de Ingenierías Marina, Náutica y Radioelectrónica, Av. Juan Carlos I, 40-11009 Cadiz, Spain

Accepted: November 23, 2020

Published online: November 25, 2020

Citation: Cordon JR, Sánchez NE, Navas JMM (2020) Female Officers on Board: Prejudices, Stereotypes and the Leadership Role. Ann Cogn Sci 4(1):174-184 
integration of women on board, with the same opportunities as men; literally, "work to increase awareness of the role of women as a valuable resource for the maritime industry" [5].

\section{The WISTA}

We must also mention the works of the Women's International Shipping \& Trading Association (WISTA International) [6] that gathers more than 3,000 women around the maritime industry, not only seafarers, but executives from around 40 countries all around the world, particularly in western and more developed countries. Among other works it is worth to mention the document by the name Gender Diversity: Towards Building and Maintaining a Diverse Shipboard Team, which in their own words is a 'booklet is a joint effort by Anglo-Eastern Ship Management Limited and the International Seafarers' Welfare and Assistance Network (ISWAN) [7] "to encourage the reader to embrace the concept of diversity on board merchant ships". These works discuss the topics of diversity, gender, discrimination, harassment, isolation and attitudes towards women on board. Sadly, these subjects are based on perceptions about the challenges that female seafarers have to face, not being grounded on tangible data.

In addition, they also host many events, workshops, conferences and promote prizes to increase the visibility and the presence of the women in the maritime sector.

\section{State of the question}

According to Carol-Dekker and Khan [8] discrimination against women on board can make the work environment very stressful for women, subsequent investigation revealed that abusive practices against female cadets were common in the fleet. Manzano [9] in an extensive work reports that sexual harassment is not only directed at female seafarers, but that some male navigators become vulnerable when they do not fit into the male hegemonic category. The attitude towards women in many cultures range from paternalism to harassment [9]. Many men still do not tolerate the presence of women on board, especially when physical strength is required for the job, this can lead to a certain condescendence or the perception of women as inferior or unfit for the task.

Remarkably, the World Maritime University (WMU) [10] has compiled a selection of articles on the subject in the book Maritime women: Global leadership [11].

WMU is committed with the female integration in this traditionally male world, this way hosted a conference in 2014, whose main conclusions were, literally:

- A declaration that IMO Members States will support the career development and mentoring of women in the maritime sector;

- Special reports at IMO's Technical Cooperation Committee and the Councils on the conference; and

- The formation of the WMU Women's Association (WMUWA) to complement and support the global network of Women's Associations developed and encouraged by IMO under their 25-year-old program on the Integration of Women into the maritime sector [11].
This conference insisted in the need to strength the role of women in the maritime sector and share experiences between countries.

\section{The pipeline problem}

The pipeline problem, referred by Gipson, et al. [12] notices that some researchers have pointed to the shortage of qualified women as a contributing factor to the gender gap in leadership roles [13]. The webpage Catalist [14] reports that male-dominated industries and occupations are particularly vulnerable to the entrenchment of male stereotypes that make it even harder for women to stand out. In the United States, only 6.6 per cent of women worked full-time in male-dominated occupations in 2017. They also point out how women working in male-dominated industries face a variety of challenges, including widespread stereotypes, such as that of the mother caregiver, or the existence of the view that women are strange people in this environment and threaten the norm.

On the other hand, the proportion of women in decision-making positions worldwide is increasing. In 2019, $29 \%$ of senior management positions were held by women, the highest figure ever recorded, although these proportions differ by region. In India, only $20 \%$ of women hold executive positions, while in Europe, North America and Australia the percentage rises to $30 \%$ [15].

Mackenzie [16] speaks about the "Leaky Pipeline", the loss of women in technical studies, and she concluded:

- That is not the choose of women not to progress in their careers,

- Work-life balance and having a family is the main problem,

- The roles of women in these works are vital.

In her study, Mackenzie also reported the results of a survey carried out by IMarEST, [17] in 2013, showing that key issues were:

- The lack of "strength in numbers": Women usually work on ferries and cruise ships, being always a minority on board.

- The nature of a "Mobile Career", and the hampering of family life.

- Legacy, discrimination, the lack of female roles as mariners, etc.

- Perceived Excuses for Discrimination: Accommodation issues, women are usually designated for catering jobs, and so forth.

It is especially noteworthy the report by Kitada [18] about work-life balance, in particular motherhood. She interviewed 36 female seafarers, including ten mothers. They reported a lack of freedom in choosing to continue sailing. In fact, only five mothers returned on board after children grown up. This work also speaks about the impact of the absence from home, concluding that women are always challenged by gender roles. 
Another chapter surveys about training opportunities, and exchange programs between academies [19]. In the Massachusetts Maritime Academy, the proportion of female cadets is only $12 \%$, and seems to be the same across the country. For instance, in Spain the proportion was 19.8\% in 2019 [20]. The fact is, despite those percentages of cadets, the presence of female officers in the fleet is sometimes residual. For instance, in a historic Company in Spain, such as Trasmediterranea, focused on the ferry market, the percentage of female officers is $10.7 \%$ (data from the Company itself). Chinese researchers report only $2 \%$ of female officers presence in that country [21].

\section{The congruence of roles theory}

According to the theory of role matching [22], prejudice can arise from the relationships that people perceive from the characteristics of a group, and the requirements that those roles place on the people willing to occupy it. Prejudice can occur when a stereotype does not match the attributes that certain people, who are candidates for those roles, are supposed to have. According to these authors, when a member of the stereotyped group and an incongruent role come together, this incongruity diminishes the evaluation of the individual as a member of the group. The prejudice towards women leaders derives from the inconsistency between the stereotyped characteristics of women and the requirements of the leadership role.

Hence, this theory is based on the gender role construct [23] which indicates that social roles are shared expectations about people in a category, and gender roles would be consensual beliefs about the attributes of men and women.

According to Eagly [24] these gender expectations are normative, as they describe qualities or behaviours that are desirable for each sex. Cialdini \& Trost [25] talk about descriptive rules, which include what the group members do and precautionary rules which are the expectations about what they should do. Therefore, gender stereotypes are derived from observations of persons performing social roles typical of each sex, in particular, men's performing the role of family livelihood and higher status, as well as women's roles as housewives and lower status [26].

Fundamental to social role theory is that most of these beliefs about gender belong to communal and traditional attributes [24]. Typical characteristics of women include primarily a concern for the well-being of other people; for example, being loving, helpful, kind, sympathetic, interpersonally sensitive and friendly. Men are attributed with assertive, controlling and confident tendencies, being aggressive, ambitious, dominant, energetic, independent, self-reliant, self-assured, and prone to act as a leader. There is abundant evidence in the literature about the beliefs on ideal men and women.

Specifically, the presence of characteristics traditionally associated with a particular gender [27], own beliefs about ideal stereotypes [28], and gender role prescriptions [29].

To our purposes, the key part of this theory is the congruence between the leader's role and gender roles, as well as the theory of role congruence and its ability to identify factors that influence when considering congruence between gender roles and others, especially leadership roles, as well as specifying key factors and their consequences on prejudice. According to Eagly \& Karau [22] prejudice against leading women is inherent in the role of the female gender, due to the inconsistency between expectations about women's behaviour and expectations about leadership conduct.

Other authors [12] have examined gender differences in leadership style, finding evidence for similarities in leadership style between women and men. These studies also focus on the importance of context, type of task, group composition, organizational culture and industry or sector.

But, continuing with the theory of role congruence, prejudice against women leaders can lead to a less favourable evaluation of women's potential for leadership because said ability belongs to the male stereotype, and a less favourable evaluation of women's actual leadership behaviour because such behaviour is perceived as less desirable in women than in men. In this way, women may be hindered from accessing leadership positions, as they should either conform to the role assigned to their gender role, or take on the role of leader by failing according to their stereotype (e.g. motherhood).

According to Eagly \& Karau [22] these two forms of prejudice should result in women having less access to leadership roles than men and more difficulty in succeeding.

Eagly \& Karau [22] also refer to the conditions that moderate the bias of inconsistency of functions. These include the masculinity of the leadership role, the gender of the recipients and cultural variations, among others, which are key in a sector as traditional as merchant marine.

\section{Gender differences and leadership styles}

Blake \& Mouton [30] coined the term "leadership style", defined as the "relatively stable" set of behaviours exhibited by a leader. Blake \& Mouton [30] labelled the axes on which leadership can be represented as "concern for production" and "concern for people". It is not our aim to go into the description of all the theories about leadership styles that exist in the literature, but to point out the gender differences in leadership styles. Based on the meta-analysis carried out by Eagly \& Johnson [31] on this issue, which included 167 studies, showed that women led with more democratic and participatory styles than men and that men led in a more autocratic or directive manner than women. With respect to task-oriented and interpersonal relationship-oriented styles, it was found that women were slightly more relationship-oriented than men, and there were no differences in task-oriented style. Other studies have reported more gender differences in other aspects of leadership-see the work of Gipson, et al. [12]. However, other studies indicate that men and women do not differ consistently in their style of leadership roles [32]. These papers pointed out that women tended towards interpersonal leadership as opposed to task-oriented leadership [32]. Thus, there is no strong pattern of women adopting a relationship-oriented style in the workplace, but rather contradictory outcomes. For our purposes it is more interesting as a 
moderator the type of industry where leadership is exercised, as merchant marine is a masculine-oriented sector. Gardiner \& Tiggemann [33] reported that there were no differences in interpersonal leadership style in male-dominated industries, but in female-dominated industries, women showed higher rates of interpersonal leadership style than men. In relation to the level of participation of followers, male leaders operate more autocratically than female leaders and, conversely, women lead with a more democratic style than men [31,32].

\section{The need for reliable data}

BIMCO is now the largest international maritime transport association, with around 1,900 members worldwide. Provides a wide range of services to its members, including boat owners, operators, managers, brokers, and agents. The latest fiveyear BIMCO/ICS Manpower Report predicts a shortage in the supply of seafarers [34]. The report identifies a current shortfall of about 16,500 officers (2.1\%), predicting a need for an additional 147,500 officers by 2025 . The majority of officers will come from the Philippines and Russia, followed closely by Ukraine and India.

As stated, many studies try to understand the challenges that women face on the fleet, but the vast majority lack of a solid data-ground-basis to draw valid conclusions.

Our intent was to take a picture of today's panorama on the thoughts of female officers, their problems and attitudes, trying to reach as many women as possible. This is a study entirely apart from gender policies, and tries to avoid any bias in this regard. It only seeks to reflect the reality as it is perceived by women on board.

Our working hypothesis will be:

- We expect to find prejudice towards female officers, due to role inconsistency.

- Women perceive more obstacles to access leadership positions (first officer, captain or chief engineer).

- Cultural differences are expected in the access to leadership positions.

- The demands of work/life balance may delay the professional career in a decisive way.

- The existence of situations of sexual harassment.

- Women officers will lead with a more participatory and democratic style than men.

\section{Materials and Method}

\section{Materials}

A questionnaire was developed by a team of psychologists and seafarers (both women and men), divided in several sections comprising questions regarding:

1. Socio-Demographic factors: Such as age, marital status, type of contract, position on board, qualification, experience and environmental components.

2. Labour factors: Discrimination perceived, support, some questions about the feelings of having to perform better than male officers, stressing factors, different treatment for being a woman and family tradition.

3. Work-Life Balance: With questions about motherhood, family life, relations, work satisfaction, relationships on board, etc.

4. Leadership Style: This section tries to identify any dissimilar behaviour within colleagues, port staff and subordinates because of gender differences, focusing on leadership characteristics.

5. Harassment Situations: Clear or veiled situations of harassment from superiors, colleagues or any other. The use of a masculine behaviour. The ability to handle unpleasant situations.

6. Finally, a free section for suggestions.

The survey is currently online, so it is accessible at https:// forms.gle/f3GdmBLZkHfKDuFn6. It is our intention to leave it online as long as possible and to keep getting answers.

Data is publicly available in the Mendeley dataset repository at https://data.mendeley.com/datasets/4ffk2hbz32/ draft?a=3d7c2f31-1b46-4ef9-abc0-dc9e1bc87190

The items are five-point Likert type scale, ranging from never to always, or strongly disagree to totally agree, when applicable.

The software used was the Google Docs platform and IBM SPSS v.24.

\section{Method}

A team of Seafarers and Psychologists developed the first version of the survey, then nine female Master Mariners and a Chief engineer, all in active, were contacted to act as experts. They made several suggestions, adding new questions, removing or changing items considered erroneous or badly worded.

Additionally, a national trade union representative of female workers from transport sector was interviewed and gave her opinion and hints. This representative also acted as a bridge with the ETF [35] to provide support and spread the survey.

The first version of the questionnaire was redacted in Spanish, then translated into English by two independent translators. This way, there are two versions: One in Spanish for Spain and Latin-American countries, and the international version in English; both online since March 19 ${ }^{\text {th }}, 2019$ on Google Docs platform.

The survey was distributed by social media such Facebook groups, WISTA groups (but without official support from this organization), contacts across Academies and Universities, the ETF and email, by word-of-mouth traditional method.

We decided to proceed with the data analysis when the answers dropped drastically.

\section{Results}

By September, 2019, 92 women had answered the survey 
in Spanish, and 63 in English. Firstly, we show descriptive data and after that with the item analysis.

\section{Sample statistics}

The Age ranged from 21-years-old to $50(\mathrm{M}=33.19, \mathrm{SD}=$ 6.913). Experience varies from 1 to 30 years sailing $(M=5.81$, SD = 5.26) (Table 1 and Table 2).

Relation with the Shipping Company is mainly permanent

Table 1: Resumes the professional qualification of the participants.

\begin{tabular}{|l|l|l|}
\hline Professional Qualification & Frequency & Percent \\
\hline Chief Engineer & 5 & 3.3 \\
\hline First Officer & 39 & 25.7 \\
\hline First Engineer & 6 & 3.9 \\
\hline Master Mariner & 43 & 28.3 \\
\hline Other & 19 & 12.5 \\
\hline Second class engineer & 10 & 6.6 \\
\hline Total & 152 & 100 \\
\hline
\end{tabular}

Table 2: Condenses their current position on board.

\begin{tabular}{|l|l|l|}
\hline Current Position & Frequency & Percent \\
\hline Captain & 5 & 3.3 \\
\hline Chief Engineer & 2 & 1.3 \\
\hline First Officer & 36 & 23.7 \\
\hline Currently, not sailing & 38 & 25 \\
\hline First engineer & 3 & 2 \\
\hline Other & 11 & 7.2 \\
\hline $2^{\text {nd }} / 3^{\text {rd }}$ Officer & 43 & 28.3 \\
\hline $2^{\text {nd }} / 3^{\text {rd }}$ engineer & 13 & 8.6 \\
\hline Valid total & 152 & 100 \\
\hline
\end{tabular}

(51.3\%) rather than temporary, by a slight difference. They mainly work in fixed routes than in tramp or non-fixed (112 to 40). Figure 1 summarized the types of vessels they have been on board. The "Other" category comprises ships as Cable, Cement-carrier, Large fishing vessels, Dredges, Large Yachts, Hospital vessels and Search and Rescue.

The sample shows a wide range of nationalities, with a

Table 3: Nationalities.

\begin{tabular}{|l|l|l|}
\hline Nationality & Frequency & Percent \\
\hline Missing values & 2 & 1.3 \\
\hline Algerian & 1 & 0.6 \\
\hline Argentina & 1 & 0.6 \\
\hline Australian & 1 & 0.6 \\
\hline Chinese & 1 & 0.6 \\
\hline Colombian & 1 & 0.6 \\
\hline French & 7 & 4.5 \\
\hline German & 1 & 0.6 \\
\hline Greek & 1 & 0.6 \\
\hline Indian & 11 & 7.1 \\
\hline Italian & 1 & 0.6 \\
\hline Italian/Greek & 1 & 0.6 \\
\hline Mexico & 2 & 1.3 \\
\hline Panama & 8 & 5.2 \\
\hline Spanish & 110 & 71.4 \\
\hline Timorese & 1 & 0.6 \\
\hline Tunisian & 1 & 0.6 \\
\hline Uruguay & 1 & 0.6 \\
\hline USA & 2 & 1.3 \\
\hline Total & 154 & 100.0 \\
\hline & & \\
\hline
\end{tabular}

\section{Type of Vessel}

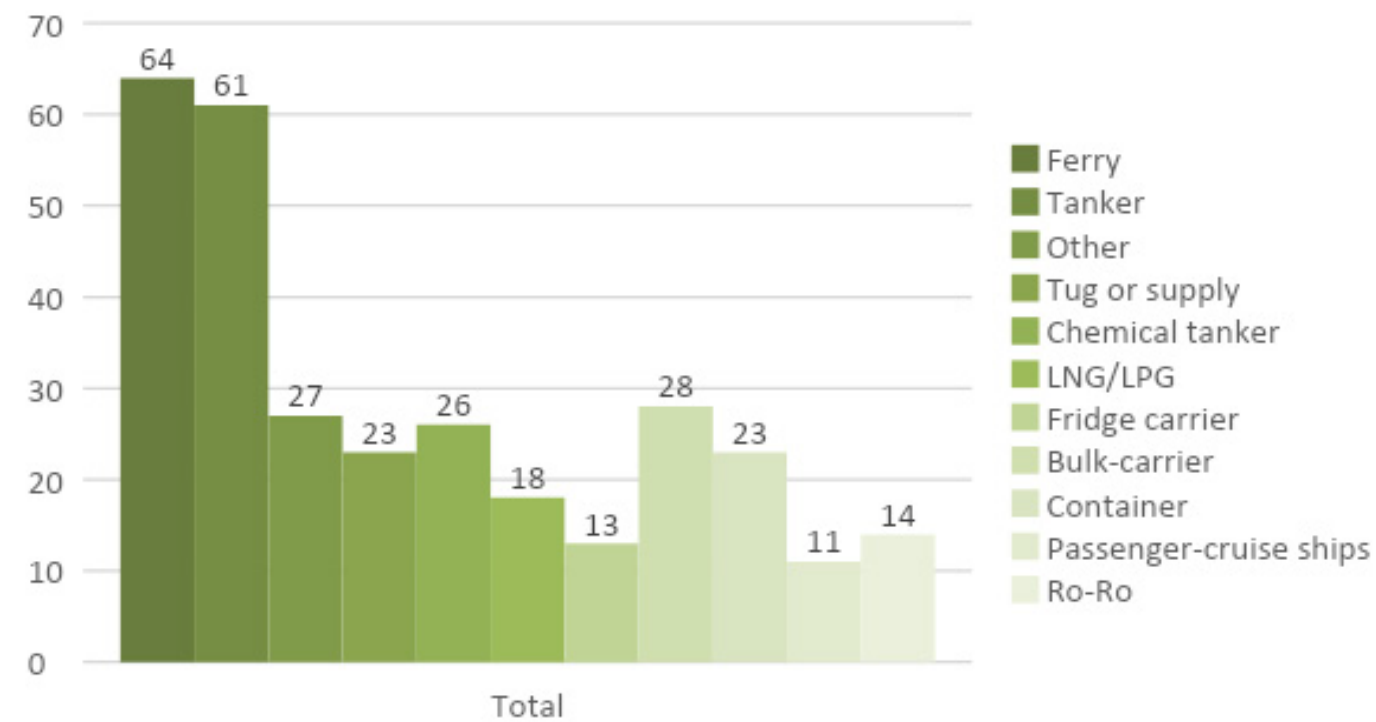

Figure 1: Types of vessels. Figures are totals. 


\section{Relationships (\%)}

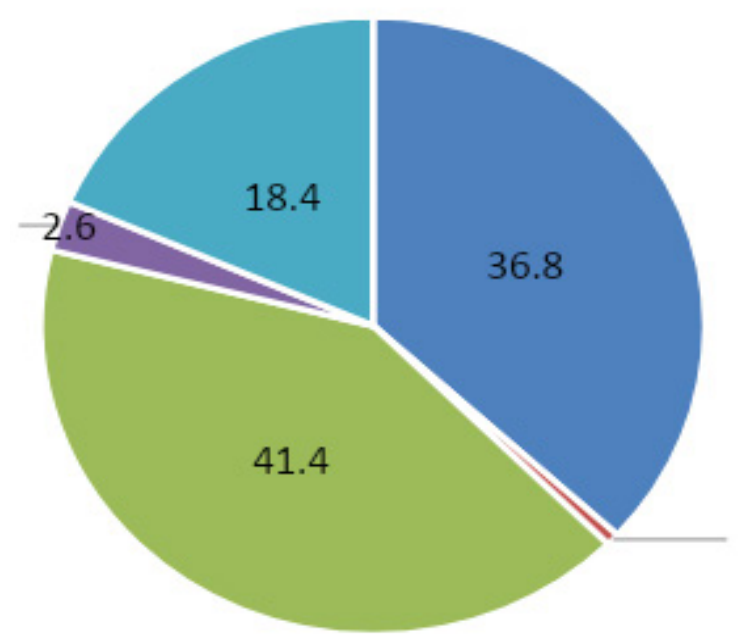

In couple

Married

Single

Single mother

With partner and children

\section{7}

Figure 2: Relationships of participants. Figures are percentages.

Table 4: Labour conditions items.

\begin{tabular}{|l|l|l|}
\hline & Mean & Std. Deviation \\
\hline I have experienced on board discrimination for being a woman & 2.71 & 0.91 \\
\hline I have experienced onboard discrimination for racial or cultural reasons & 1.49 & 0.76 \\
\hline I feel that I cannot be promoted in this company because I am a woman & 2.6 & 1.28 \\
\hline My male companions support me & 3.47 & 1.04 \\
\hline I think I have to try harder physically than my peers & 3.45 & 1.46 \\
\hline I feel I must perform better intellectually than my male peers & 3.74 & 1.4 \\
\hline My superiors in rank are more demanding for being a woman & 3.06 & 1.4 \\
\hline My colleagues act condescending with me for being a woman & 2.84 & 1.2 \\
\hline Physical effort is the most stressful thing in my job on board & 1.98 & 1.08 \\
\hline The psychological burden is the most stressful thing in my position on board & 3.57 & 1.23 \\
\hline Sometimes I take advantage of my status as a woman not to do certain jobs & 1.31 & 0.65 \\
\hline I've felt economically discriminated for being a woman & 1.51 \\
\hline Port authorities/employees have treated me differently than male officers & 2.47 \\
\hline Sometimes I have heard comments that I am Captain/Chief M. just for being a woman & 1.80 & 0.91 \\
\hline My company takes women into account when considering costumes and uniforms & 2.17 & 1.02 \\
\hline The seafaring profession is a tradition in my family & 1.95 & 152 \\
\hline Valid N (listwise) & 1.27 \\
\hline
\end{tabular}

The items with +/- 1 point from that point are highlighted in bold.

majority of Spanish respondents, as they were more readily accessible. Table 3 resumes this data.

About the Crews, they are mainly multinational, only in the cases of Ferry boats on certain Companies or Government ships the crews are comprised of a single nationality. Nations present in crews are: Bangladesh, Brazil, Bulgaria, Chile, Croatia, Cuba, Cyprus, Estonia, France, Ghana, Greece, Honduras, India, Indonesia, Italia, Lethonia, Lithuania, Malaysia, Morocco, Nicaragua, Panama, Philippines, Peru, Poland, Romania, Russia, Spain, Sri Lanka, Sweden, UK, Ukraine and USA. Prac- tically the same ranges of countries are present in Officers' nationalities.

About the relationships of contestants, they are summarized in Figure 2.

\section{Labour factors}

Items in this section are reported on Table 4. Three is the central point of the scale, so items with $+/-1$ point from that point are highlighted in bold. 
Table 5: Work-life balance.

\begin{tabular}{|l|l|l|}
\hline Work-Life Balance & Mean & Std. Deviation \\
\hline Work is the first priority in my life & 2.96 & 1.12 \\
\hline I try to have a balance between work and family life. & 4.17 & 1.01 \\
\hline This job hinders me from having a normal family life (with a partner and children). & 3.72 & 1.27 \\
\hline This job has conditioned my motherhood & 3.67 & 1.54 \\
\hline I am satisfied with my professional life & 3.85 & 0.97 \\
\hline I am satisfied with my personal life & 3.98 & 0.98 \\
\hline I lam satisfied with my male colleagues & 3.72 & 0.87 \\
\hline I like to work with men & 4.26 & 0.82 \\
\hline I'd rather work with men than with other women. & 2.88 & 1.4 \\
\hline I prefer to be commanded by men & 2.25 & 1.24 \\
\hline Valid N (listwise) & 147 & \\
\hline
\end{tabular}

The items with +/- 1 point from that point are highlighted in bold.

Table 6: Leadership style.

\begin{tabular}{|l|l|l|}
\hline Leadership Style & Mean & Std. Deviation \\
\hline I do things differently on board for being a woman & 2.23 & 1.26 \\
\hline I like to treat subordinates differently than other male officers & 2.11 & 1.21 \\
\hline I have a more participative style of command than my male colleagues & 3.23 & 1.32 \\
\hline I like to hear the opinions of my fellow officers before making a decision & 3.75 & 0.93 \\
\hline The Port staff (dockworkers, etc.) respect me less than my fellow men. & 2.35 & 1.01 \\
\hline I feel that the subordinates respect me less than my male colleagues & 2.17 & 0.96 \\
\hline Valid N (listwise) & 152 & \\
\hline
\end{tabular}

Table 7: Harassment situations.

\begin{tabular}{|l|l|l|}
\hline Harassment Situations & Mean & Std. Deviation \\
\hline My colleagues treat me differently (in personal dealings) & 2.58 & 1.12 \\
\hline I have experienced sexual harassment on board & 1.96 & 0.99 \\
\hline I've suffered advances from fellow officers on board & 2.3 & 1.02 \\
\hline I have suffered advances by subordinates & 1.99 & 0.95 \\
\hline I feel like I can't act like a woman so as not to make misunderstandings & 2.91 & 1.29 \\
\hline On board, I intend to adopt a role of masculine behavior & 2.68 & 1.27 \\
\hline I have had to report an unpleasant situation due to harassment or sexual assault on board & 1.60 & 0.93 \\
\hline I am able to handle these situations alone & 4.11 & 1.09 \\
\hline I feel the respect of the entire crew as a woman and as an officer & 3.77 & 0.99 \\
\hline Valid N (listwise) & 149 & \\
\hline
\end{tabular}

\section{Work-life balance}

Items in this section are presented on Table 5.

\section{Leadership style}

Data is presented on Table 6.

\section{Harassment situations}

Data is resumed on Table 7.

Differences between samples and cultural differences
Currently, Spain is the $4^{\text {th }}$ country in the Women's Workplace Equality Index [36], only behind Australia, Canada and New Zealand, with an overall score of 92.9/100. That means that our global sample can be biased by a majority of Spaniards, coming from a country leader in gender equality.

To detect differences and deal with this question t-test were performed between means in every item, using $\mathrm{BCa}$ (Bias Corrected and accelerated, 1000 samples) bootstrap method to avoid some problems with normality in few items. Significant differences were found in only 8 items of the total, as shown in Table 8. 
Citation: Cordon JR, Sánchez NE, Navas JMM (2020) Female Officers on Board: Prejudices, Stereotypes and the Leadership Role. Ann Cogn Sci 4(1):174-184

Table 8: Items with differences between groups.

\begin{tabular}{|l|l|l|l|l|}
\hline t-test for Equality of Means & $\mathbf{t}$ & df & Sig. (2-tailed) & Mean Difference \\
\hline Labour 1 & -2.83 & 110.53 & 0.01 & -0.43 \\
\hline Labour 7 & -3.08 & 141.00 & 0.00 & -0.73 \\
\hline Labour 12 & -2.44 & 141.00 & 0.02 & -0.38 \\
\hline Labour 14 & -2.88 & 141.00 & 0.00 & -0.49 \\
\hline Balance 3 & 2.04 & 141.00 & 0.04 & 0.44 \\
\hline Leadership 2 & -2.9 & 141.00 & 0.00 & -0.61 \\
\hline Leadership 3 & -2.54 & 122.65 & 0.01 & -0.53 \\
\hline Harassment 8 & 2.37 & 75.72 & 0.02 & 0.50 \\
\hline
\end{tabular}

Note: Positive Mean differences indicate Spanish sample Mean is higher and negative, lower.

In terms of cultural differences, the sample has been stratified into quartiles based on the web ranking Women's Workplace Equality Index [36]. In this way, it has been possible to perform a one-way ANOVA to check if there are differences in the items based on this ranking. Significant differences have been found in the items, so it has been possible to make a one factor ANOVA to check if there are differences in the items based on this ranking. Significant differences have been found in the items I have had to report an unpleasant situation due to harassment or sexual assault on board, $\mathrm{F}(3,146)=$ $3.325, \mathrm{p}=0.021$; My superiors in rank are more demanding for being a woman, $\mathrm{F}(3.147)=3.163, \mathrm{p}=0.026$; and The Port staff (dockworkers, etc.) respect me less than my fellow men, $F(3.146)=2.699, p=0.048$. The results indicate higher scores at the lower quartile in the country's ranking.

\section{Female officers' opinions and experiences}

At the end of the survey, the participants could freely leave some comments or experiences they may have had. Many of these comments are quite interesting. In this sense, many of the opinions and experiences can be understood as an interview, encompassing various aspects of those evaluated in the items. The majority of the comments underline the ideas stated on the items, but in some cases there are some experiences about harassment and bad situations on board, they are only a few, anyway.

\section{Discussion}

\section{Sample characteristics}

The main objective is to detect how prejudice works in one of the probably most historically masculine industries and with a strong tradition of clearly masculine characteristics, particularly in the leadership roles that officer positions entail. Another objective of this survey is to gather data about the challenges that women face on board as Officers, told by themselves, so researchers now are able to draw conclusions based on more than perceptions or a few interviews. Nevertheless, the secondary goal is to motivate the research on this field. We welcome any investigator across the world to spread this survey, or even use it at their discretion. Anyone interested in getting the data just can just contact any of the authors.

One of the main drawbacks of this research is the sample size and its composition, with a $71 \%$ of Spanish women. Definitely, it embodies the situation in Spain with fidelity. But the great heterogeneity of the whole sample, with 18 countries represented from all over the world, can be a very good start point for future study. However, we only found differences statistically significant in 8 out of 41 items, this suggests that the opinions are not so different across diverse countries.

The sample is heterogeneous enough in terms of ages, qualification, position on board and experience, giving a good picture of the fleet situation at the present time. It is quite difficult to determine the percentage of women sailing as officers nowadays. Without the implication of the IMO itself or the Shipping Companies, it is impossible to determine a reliable figure. In this regard, we have to thank Trasmediterranea for its support. This Company has also implemented a gender equality plan to ensure that women can stay on board after maternity, for example. Another question is what happened with the female cadets after leaving the Academy. The data in Spain points that only half of them finally enter the market, most probably in other countries this proportion is smaller.

The sample also represents a wide variety of Flags, Crews and type of vessels, but with a clear preference for ferry boats and tankers, two very unalike ships. Also, the majority of the women are in a relation of some kind, and around $20 \%$ of them have children, similarly we found no correlation between being mother and stay on board, so many women are collating the roles of mother and a seafarer. Likewise, we found no correlation between motherhood and the type of contract they have with the Shipping Company.

\section{Labour factors}

We focused on items whose mean differs more than one point from the central mark (3), we also look at the standard deviation, suggesting there is an agreement on the sample, and the item should be pointing in some direction.

The first item that caught our attention was the one referred to discrimination for racial or cultural reasons, with a mean of 1.40 and SD of .76, even statistically lower in the Spanish sample, this suggests that the vast majority of female officers had not experienced that type of discrimination. The same happens with the related to physical effort.

But the lowest mean and SD correspond to the item 
Sometimes I take advantage of my status as a woman to not do certain jobs. This is, in our opinion, a clear message about women's commitment with their work and self-confidence and clearly shows determination and empowerment. In this sense, the assumptions of the first two hypotheses have not been fulfilled, since female officials do not perceive discrimination because they are women, nor do they feel that there are more obstacles to accessing leadership positions. Even item I have experienced onboard discrimination for racial or cultural reasons presents a clearly lower average on the scale. However, there are cases of discrimination for cultural reasons, in a particular way, since -as can be seen in some testimonies- sometimes there are cases of discrimination, both because of inconsistency of roles (women should be at home), and for cultural reasons.

Family tradition does not seem to be a factor to be seafarer, likewise, women do not feel discriminated economically.

\section{Work-life balance}

The most salient items in this scale could be the referred to the effort that female officers put on balancing work and family, it would be interesting to compare this result with a male sample, as we have the perception that in modern societies this is a great concern for the public. But of course, the seafarers' work particular characteristics made this a crucial point of interest. Here again, we cannot claim that our hypothesis is fulfilled about the delay that can occur in one's professional career due to the reconciliation with family life. Although the officers are clear that family life is very important and they make great efforts to reconcile it, this does not seem to slow down their career in the civil marine. However, a fact that seems to contradict this statement is that $41.6 \%$ of the participants do not have a partner. It would therefore be interesting to see whether this percentage is also common among men. Hence, it seems that the characteristics found by Gibson predominate, since there seems to be evidence in favor of the similarities in leadership style between women and men given the importance of the context and the type of sector. That is to say, the environment establishes a leadership style that does not admit differential behaviour patterns, imposing the context, the type of task and the organizational structure.

Another salient output is that women like to work with men, which may be a trait required for this kind of job. It is worth a further analysis in our opinion.

\section{Leadership style}

We were expecting this output, because in our opinion-based on experience, there is no difference in leadership style between genders on board. This kind of job requires a behaviour fixed by roles and position, inside a vertical pyramid-type organization, leaving small room for a more participative style. The Spanish sample presents differences in two items with the international, but not so far from the mean to represent a real change in terms of leadership style. From professional opinions and experiences, it could be foreseen how leadership styles were not at all going to be separated from those used by men, however, the literature states some differentiation. In our opinion the only possible leadership style in a typically pyramidal organization, with strong hierarchization and well-defined roles, is more directive than participatory, with no possibility of applying leadership styles more in vogue today. It is proven that women adapt perfectly to their position and exercise leadership effectively.

\section{Harassment situations}

Once again, we are not able to say that our hypothesis about harassment situations has been fulfilled, since the vast majority of women claim not to have suffered from them (although we find some testimonies to the contrary, they seem to be a minority).

The majority of women have not experienced harassment situations on board, as the mean is "almost never". This can be seen as an advance in women rights and equality. This piece of evidence is supported with the result of the item about the need of reporting unpleasant situations. Also, the mean of the item related to the ability to handle these situations (Higher in the Spanish sample) speaks about the self-confidence of these women. Obviously, unpleasant situations and advances are still present, but perhaps no more than in any other work environment. We believe that there can be also a cultural gap in this matter that have to be thoroughly studied, still the output is clear.

\section{Differences between samples}

Only in 8 items we found some differences between Spanish and international sample. Regrettably, we could not collect more data on certain countries to do an extensive study, but given the research on gender differences, we can suppose that in the western-culture nations the results would be more alike to the Spanish group. Cultural differences are still out there, and more implication of the IMO and National Administration is needed to get a valid sample to perform some test between countries from different social basis. While cultural differences must undoubtedly exist, the fact is that the officers surveyed do not seem to report this, as these differences are only apparent in three items of the total. This may indicate how women who decide to work in this environment are willing to overcome the social, labor and cultural barriers they face, making themselves respected despite the harsh environment. Evidently, the sample of women coming from countries in the second, third and especially the fourth quartiles is scarce (20 out of 154). This may be due to the fact that so very few women from these countries have access to positions of responsibility in the fleet or that our questionnaire has not been able to access them.

However, differences are so small that we can conclude that there is a "common spirit", any kind of collection of traits and behaviours that female officers have in common. The firm intention to thrive in what is probably the most masculine profession, the spirit of endurance and the passion for sailing are many of them. We can see them in the experiences told by many of the participants.

\section{Female officers' opinions and experiences}

We can see in the experiences told by many of the contes- 
tants a lot of the information picked in the survey. We think that these stories speak by themselves and point out that there is still a long way to complete equality and to see as completely normal a woman in a position normally occupied by a man, particularly in certain countries. In some cases, the opinions seem to contradict the majority, as they are personal experiences and- that is why we find them interesting. They reflect only particular cases, and the predominantly opinion is in line with the principles, interests and experiences captured by the survey items.

We again welcome researchers all over the world to expand this survey, as it will be online for a long time, we expect to have new results. Any investigator interested in the data, just email the correspondent author.

But, again, if IMO really intends to impulse their policy of equality on board and attract more women to the fleet it is mandatory to work alongside with National Administrations and Shipping Companies to facilitate solutions to the factors that we have detected. More sound investigation in certain countries is compulsory if we want draw more conclusions, so we encourage interested researchers to continue this work.

\section{Acknowledgements}

The authors wish to thank the Trade Union Comisiones Obreras (CCOO), its representant in SASEMAR and the chairperson responsible of women policies in Spain. They provided some useful tips and ideas to develop the survey. Also, the support of the Spanish representative in the The European Transport Workers' Federation (ETF). Without their implication it could be impossible to reach so many officers.

We have to thank as well The Director of Health Risk Prevention of the shipping Company Armas-Trasmediterranea for his information and ideas.

\section{Conflict of Interest}

We have no known conflict of interest to disclose.

\section{References}

1. UIC (2019) Women and transport: An opportunity for the industry and for new forms of mobility, by Catherine Trautmann.

2. ILO (2019) Women in the transport sector. ILO, Geneva.

3. IMO (2019) Women in the maritime.

4. IMO (2019) IMO's gender programme: New logo to increase visibility for women in maritime.

5. IMO (2013) Busan declaration.

6. WISTA International (2019) Women's international shipping \& trading association.

7. ISWAN (2019) Promoting and supporting the welfare of seafarers.

8. Carol-Dekker L, Sultan S (2016) Reflections on the psycho-social distress within the international merchant navy seafaring community. Journal of Psychology 7: 53-60.

9. Joanne V Manzano (2014) Filipino crosscurrents: Oceanographies of seafaring, masculinities, and globalization by kale bantigue fajardo. Philippine Studies: Historical and Ethnographic Viewpoints 62: 289-292.
10. WMU (2020) Serving the global maritime community through education, research and capacity building. World Maritime University.

11. Kitada M, Williams E, Froholdt LL (2015) Maritime women: Global leadership. Springer.

12. Gipson AN, Pfaff DL, Mendelsohn DB, et al. (2017) Women and leadership: Selection, development, leadership style, and performance. The Journal of Applied Behavioral Science 53: 32-65.

13. Carli LL, Eagly AH (2007) Overcoming resistance to women leaders: The importance of leadership style. In: Women and leadership: The state of play and strategies for change, Jossey-Bass, 127-148.

14. (2020) Women in male-dominated industries and occupations: Quick take. Catalyst.

15. (2020) Female business leaders: Global statistics. Catalyst.

16. Mackenzie B (2015) The "leaky pipeline": Examining and addressing the loss of women at consecutive career stages in marine engineering, science and technology. In: M Kitada, E Williams, LL Froholdt, Maritime Women: Global Leadership. (edn), Springer Berlin Heidelberg, 69-81.

17. (2019) Institute of marine engineering, science \& technology.

18. Kitada M (2015) Absent mother sailors: How possible is it to do the impossible? Maritime Women: Global Leadership, Springer, 113-126.

19. Chen Q (2015) Let numbers speak: Job opportunities and international exchange programs for female maritime cadets. Maritime Women: Global Leadership, Springer, 129-141.

20. (2019) Instituto de la mujer y para la igualdad de oportunidades.

21. Zhang P, Zhao M (2015) Chinese Women Seafarers: Past, Present and Prospects. In: M Kitada, E Williams, LL Froholdt. (edn), Maritime Women: Global Leadership, Berlin, Heidelberg, Springer, 235-253.

22. Eagly AH, Karau SJ (2002) Role congruity theory of prejudice toward female leaders. Psychological Review 109: 573-598.

23. Biddle BJ (1986) Recent developments in role theory. Annual Review of Sociology 12: 67-92.

24. Eagly AH (1987) Sex differences in social behavior. A social-role interpretation. Taylor \& Francis Group.

25. Cialdini RB, Trost MR (1998) Social influence: Social norms, conformity and compliance.

26. Diekman AB, Eagly AH (2000) Stereotypes as dynamic constructs: Women and men of the past, present, and future. Personality and Social Psychology Bulletin 26: 1171-1188.

27. Helmreich RL, Spence JT (1978) The work and family orientation questionnaire: An objective instrument to assess components of achievement motivation and attitudes toward family and career. American Psychological Association, Journal Supplement Abstract Service.

28. Wood W, Christensen PN, Hebl MR, et al. (1997) Conformity to sex-typed norms, affect, and the self-concept. J Pers Soc Psychol 73: 523-535.

29. Rudman LA, Glick P (2001) Prescriptive gender stereotypes and backlash toward agentic women. Journal of Social Issues 57: 743-762.

30. Blake R, Mouton J (1964) The managerial grid: The key to leadership excellence. Houston: Gulf Publishing Co, 350. 
31. Eagly AH, Johnson BT (1990) Gender and leadership style: A meta-analysis. Psychological Bulletin 108: 233-256.

32. Van Engen ML, Willemsen TM (2004) Sex and leadership styles: A meta-analysis of research published in the 1990s. Psychological Reports 94: 3-18.

33. Gardiner M, Tiggemann M (1999) Gender differences in leader- ship style, job stress and mental health in male-and female-dominated industries. Journal of Occupational and Organizational Psychology 72: 301-315.

34. BIMCO/ICS manpower report 2015.

35. ETF (2019) European transport workers' federation.

36. (2019) Country rankings. 